\title{
Pengaruh Kesejahteraan Keluarga Terhadap Citra Diri Remaja Tengah (14-17 Tahun) Di GKII Beno'honis Oelbima Kupang Nusa Tenggara Timur
}

\author{
Intan Priskila Nuban
}

\begin{abstract}
Abstrak
Tujuan penulisan skripsi ini adalah menjelaskan sejauh mana pengaruh kesejahteraan keluarga terhadap citra diri remaja tengah (14-17 Tahun) di GKII Beno'honis Oelbima Kupang-NTT. Adapun hasil penelitian dapat disimpulkan sebagai berkut: Pertama, dari 14 orang remaja terdapat 13 orang yang tergolong keluarga sejahtera I artinya bahwa kebutuhan dasar atau kebutuhan pokok telah terpenuhi dengan baik, tercapainya kebutuhan aspek sosial-psikologisnya yaitu kebutuhan untuk beribadah, mengkonsumsi protein hewani, pakaian, dalam keadaan sehat, tetapi belum seluruhnya terpenuhi dengan bukti masih ada anggota keluarga yang tidak mampu baca tulis dan memiliki penghasilan. Serta terdapat satu remaja merupakan keluarga pra sejahtera. Kedua, dalam hubungan sosial para remaja cenderung mengalami kesulitan karena disebabkan oleh faktor didikan keluarga, lingkungan masyarakat serta kondisi ekonomi atau kesejahteraan. Ini menunjukkan bahwa para remaja kurang mendapat didikan yang Alkitabiah dari orang tua dalam membangun citra diri yang benar menurut kebenaran firman Tuhan. Ketiga, remaja yang tergolong keluarga pra sejahtera memiliki citra diri yang rendah diakibatkan oleh faktor didikan keluarga, lingkungan masyarakat dan kondisi ekonomi. Keempat, dari faktor-faktor yang memengaruhi citra diri yaitu keluarga, lingkungan masyarakat, keadaan fisik, kondisi ekonomi, serta cara pandang terhadap diri sendiri hasil angket menunjukkan bahwa kondisi ekonomi sedikit saja memberikan pengaruh terhadap citra diri. Sedangkan faktor-faktor yang dominan memengaruhi citra diri remaja adalah faktor didikan keluarga, lingkungan masyarakat sehingga hal ini memengaruhi cara pandang remaja terhadap dirinya.
\end{abstract}

Kata-kata Kunci: Pengaruh, Kesejahteraan, Keluarga, Citra, Diri, Remaja. 


\section{Pendahuluan}

\section{Latar Belakang Masalah}

Kesejahteraan merupakan hal yang didambakan oleh setiap keluarga dan penting untuk semua orang, tetapi sayangnya hanya dapat diraih dengan usaha dan kerja keras. Oleh sebab itu tidak semua keluarga mengalami kesejahteraan. Salah satu penyebab sebuah keluarga tidak mengalami kesejahteraan adalah karena faktor kemiskinan. Menurut BKKBN (Badan Koordinasi Keluarga Berencana Nasional) kemiskinan didefinisikan sebagai ketidakmampuan sebuah keluarga dalam memenuhi kebutuhan sandang, pangan, dan papan atau kebutuhan pokok. BKKBN menggolongkan keluarga sejahtera dalam beberapa bagian yang terdiri atas keluarga pra sejahtera, keluarga sejahtera I, Keluarga sejahtera II, Keluarga Sejahtera III, dan keluarga sejahtera III plus. ${ }^{1}$

Banyak daerah di Indonesia yang tergolong daerah miskin, penyebab kemiskinan adalah keterampilan atau kinerja yang dimiliki masih sangat rendah. Thee Kian Wie mengatakan bahwa penyebab kemiskinan adalah keterampilan yang rendah akibat dari terbatasnya sekolah-sekolah dan perguruan tinggi di Indonesia dibandingkan dengan kebutuhan masyarakat. Mutu atau kualitas sekolah dengan biaya yang tinggi turut memengaruhi sehingga yang menikmati pendidikan hanyalah anak-anak dari golongan berada. ${ }^{2}$ Kemiskinan merupakan pergumulan yang bukan hanya menjajah negara-negara berkembang melainkan negara-negara maju. Jhon Stott menulis bahwa David Sheppard uskup Liverpool berbicara dalam ceramahceramah yang dilakukannya bahwa ia prihatin tentang muda-mudi dan problema yang berkepanjangan, tentang keterbatasan bersekolah dan perasaan terasing dan bahkan dikucilkan. $^{3}$

Ketika sebuah keluarga mengalami masalah kesejahteraan, hal ini otomatis berdampak kepada anggota-anggota keluarga yaitu suami, istri dan anak-anak. Masalah yang dihadapi oleh anak-anak berkaitan dengan masalah kesehatan, akademik, perilaku, dan sosial. Contoh masalah di bidang akademik adalah anak mengalami putus sekolah. Menurut data resmi dari kantor Komnas Perlindungan Anak (PA) tahun 2007, kasus putus sekolah yang paling menonjol tahun 2007 terjadi di tingkat SMP yaitu 48\%, dan jika digabungkan kelompok usia pubertas yaitu anak

\footnotetext{
${ }^{1}$ Nurul Annisa Prias Kusuma Wardani, Suprapti Supardi, Wiwit Rahayu, "Konsumsi Rumah Tangga Pada Keluarga Sejahtera dan Pra Sejahtera di Kecamatan Colomadu Kabupaten Karanganyar". E-Jurnal AGRISTA Ed 1.Vol.1 (2013): 2, diakses 14 Maret 2016, agribisnis.fp.uns.ac.id/wp-content/uploads/2013/01/JURNALL-Nurul-Annisa.pdf.

${ }^{2}$ Thee Kian Wie, Pemerataan Kemiskinan Ketimpangan (Jakarta: Sinar Harapan, 1981), 106.

${ }^{3}$ Jhon Stott. Isu-Isu Global Menantang Kepemimipinan Kristiani (Jakarta: Yayasan Komunikasi Bina Kasih, 1993), 304.
} 
SMP, SMA berjumlah 77\%. Dengan demikian jumlah anak usia remaja putus sekolah tahun 2007 tidak kurang dari 8 juta orang dan akibat kemiskinan maka munculnya 2,1 juta jiwa menjadi pekerja di bawah umur. ${ }^{4}$

Dari sudut pandang hubungan sosial remaja di lingkungan masyarakat juga akan menimbulkan masalah yang berkaitan dengan bagaimana cara pandang seorang remaja terhadap dirinya sendiri. Seorang remaja merasa rendah diri, pemalu yang menghambat hubungan sosialnya dengan orang lain. Contoh kasus ada seorang remaja (Dwi 14 tahun) yang melakukan aksi bunuh diri hanya karena tidak bisa membayar biaya karyawisata di sekolahnya. ${ }^{5}$ Citra diri yang buruk atau ketidakmampuan menerima kenyataan ekonomi keluarga yang rendah menyebabkan sehingga seorang remaja melakukan aksi nekat ini.

Sebuah penelitian yang dilakukan oleh Zilanawala \& Pilkauskas (2010) menunjukkan bahwa anak-anak dari keluarga miskin lebih mungkin untuk menunjukkan masalah perilaku dibanding anak-anak dari keluarga kaya, perilaku dan efeknya terlihat pada hasil akademik, kesehatan, dan pendapatan. Penelitian ini menemukan bahwa anak-anak yang berada dalam keluarga miskin skor signifikan lebih tinggi pada agresif, menarik diri dan cemas. ${ }^{6}$

Di dalam majalah Bahana Julianto dan Roswitha mengatakan bahwa remaja diperhadapkan dengan berbagai tekanan yaitu bagaimana memercayai Tuhan dan otoritas, penerimaan dirinya yang berkaitan dengan perasaan minder karena kurang cantik, kurang kaya dan lain sebagainya serta tekanan dari teman sebaya. ${ }^{7}$ Oleh karena itu orang tua diharapkan mampu untuk memberikan didikan yang tepat kepada remaja.

Jika seorang remaja mampu memahami dan menerima kekurangan ekonomi keluarganya dengan baik maka remaja tersebut melihat hal ini dari sudut pandang yang baik sehingga tetap optimis dalam menjalani kehidupan ini. Remaja yang berlatar belakang berasal dari keluarga sejahtera juga bisa mengalami citra diri yang buruk jika mereka tidak merasa puas dengan apa yang dimiliki dalam aspek yang lain.

\footnotetext{
${ }^{4}$ Syifa Hudzaifa Zahra, "Profil Resiliensi siswa SMP Terbuka Serta Implikasinya Terhadap Bimbingan dan Konseling". Jurnal Pendidikan Terbuka dan Jarak Jauh, Vol. 5, No. 1, (Maret. 2004): 59-82, diakses 17 Maret 2016, http://a-research.upi.edu .

${ }^{5}$ Liony Wijayanti dan Ihsannudin, "Strategi Peningkatan Kesejahteraan Masyarakat Nelayan Kecamatan Pademawu Kabupaten Pamekasan”, Agriekonomika Vol. 2 No. 2 (Oktober 2013): 139. Diakses 18 Maret 2016, journal.trunojoyo.ac.id/agriekonomika/article/view/433/404. 139.

${ }^{6}$ R. Anisah, "Kesejahteraan Siswa dari Keluarga Pra sejahtera," diakses 17 maret 2016, http:// eprints.ums.ac.id.04_BAB 1_I

${ }^{7}$ Julianto dan Roswitha Ndraha, Majalah Bahana. Vol 244 (Agustus 2014), 14.
} 
Masalah mengenai kesejahteraan keluarga juga terjadi di GKII Beno'honis Oelbima, banyak remaja yang tidak melanjutkan sekolah dan harus menikah muda, dan pada akhirnya mereka (remaja GKII Beno,honis) memiliki citra diri yang buruk karena faktor ekonomi keluarga yang rendah.

\section{Pokok Masalah}

Yang menjadi pokok masalah dalam penulisan skripsi ini adalah bagaimana pengaruh kesejahteraan keluarga terhadap citra diri remaja tengah (14-17 Tahun) secara khusus di GKII Beno'honis Oelbima Kupang-NTT.

\section{Tujuan Penelitian}

Tujuan utama dalam penulisan skripsi ini adalah menjelaskan sejauh mana pengaruh kesejahteraan keluarga terhadap citra diri remaja tengah (14-17 Tahun) di GKII Beno'honis Oelbima Kupang-NTT.

\section{Manfaat Penelitian}

Manfaat dari penulisan skripsi ini adalah:

Pertama, sebagai acuan bagi para remaja dalam membangun citra diri yang positif berdasarkan pandangan Alkitabiah.

Kedua, sebagai salah satu syarat untuk menyelesaikan studi di Sekolah Tinggi Theologia Jaffray Makassar.

\section{Metode Penelitian}

Metode penelitian yang digunakan adalah oleh penulis adalah metode kuantitatif yaitu melalui angket, serta melalui studi kepustakaan yaitu melalui bukubuku di perpustakaan dan metode kualitatif yaitu berupa wawancara ${ }^{8}$ dan observasi langsung ${ }^{9}$.

\section{Batasan Penelitian}

Batasan penulisan dibatasi hanya pada pengaruh kesejahteraan keluarga terhadap citra diri remaja tengah (usia 14-17 Tahun) di GKII Beno'honis Oelbima Kupang- NTT.

\footnotetext{
${ }^{8}$ Hengki Wijaya (ed.), Metodologi Penelitian Pendidikan Teologi (Makassar: Sekolah Tinggi Theologia Jaffray, 2016), 24-26.

9 Observasi adalah pengamatan dan pencatatan yang sistematis terhadap fenomena yang hendak diteliti. Ibid., 21.
} 


\section{Kepustakaan}

Anisah, R. "Kesejahteraan Siswa dari Keluarga Pra sejahtera.” Diakses 17 Maret 2016. http:// eprints.ums.ac.id.04_BAB 1_I.

Julianto dan Roswitha Ndraha. Majalah Bahana. Vol 244 (Agustus 2014).

Stott, Jhon. Isu-Isu Global Menantang Kepemimipinan Kristiani. Jakarta: Yayasan Komunikasi Bina Kasih, 1993.

Wardani, Nurul Annisa Prias Kusuma, Suprapti Supardi, Wiwit Rahayu, "Konsumsi Rumah Tangga Pada Keluarga Sejahtera dan Pra Sejahtera di Kecamatan Colomadu Kabupaten Karanganyar.” E-Jurnal AGRISTA 1, Vol. 1 (2013):2. Diakses 14 Maret 2016. agribisnis.fp.uns.ac.id/wpcontent/uploads/2013/01/JURNALL-Nurul-Annisa.pdf.

Wie, Thee Kian. Pemerataan Kemiskinan Ketimpangan. Jakarta: Sinar Harapan, 1981.

Wijaya, Hengki (ed.). Metodologi Penelitian Pendidikan Teologi. Makassar: Sekolah Tinggi Theologia Jaffray, 2016.

Wijayanti, Liony dan Ihsannudin, "Strategi Peningkatan Kesejahteraan Masyarakat Nelayan Kecamatan Pademawu Kabupaten Pamekasan." Agriekonomika 2, No. 2 (Oktober 2013):139. Diakses 18 Maret 2016. journal.trunojoyo.ac.id/agriekonomika/article/view/433/404. 139.

Zahra, Syifa Hudzaifa. "Profil Resiliensi siswa SMP Terbuka Serta Implikasinya Terhadap Bimbingan dan Konseling." Jurnal Pendidikan Terbuka dan Jarak Jauh, 5, No. 1 (Maret. 2004):59-82. Diakses 17 Maret 2016. http://aresearch.upi.edu . 